\title{
RICE HUSK PACKED BED COLUMN REACTOR TO REMOVE CADMIUM FROM LANDFILL LEACHATE
}

\section{Reaktor Packed Bed Column Berisi Sekam Padi Untuk Mereduksi Kadmium Dalam Lindi TPA}

Monik Kasman ${ }^{* 2}$, Shaliza Ibrahim² and Salmariza ${ }^{3}$

1 Program Studi Teknik Lingkungan, Universitas Batanghari, Jambi, Indonesia.

2 Departemen Teknik Sipil, Universiti Malaya, Lembah Pantai 50603 Kuala Lumpur, Malaysia

3 Baristand Industri Padang JI. Raya LIK No. 23 Ulu Gadut Padang 25164

*e-mail: emka_engineer@yahoo.com

Diterima: 26 Juli 2013, revisi akhir: 20 November 2013 dan disetujui untuk diterbitkan: 6 Mei 2014

\begin{abstract}
The landfill leachate can be a major problem due to large variability of high organic, inorganic, heavy metal content and toxicity characteristics from landfill leachate such as cadmium. Thus, this study was aimed to observe the application of rice husk packed bed column to reduce cadmium from landfill leachate. Experiment was conducted in gravity down flow system by pumping landfill leachate into packed bed column. The effect of influent flow rate to adsorption capacity was studied by varying flow rate $(5 \mathrm{~mL} / \mathrm{min}$ and $10 \mathrm{~mL} / \mathrm{min})$. The effluent-influent concentration ratio $\mathrm{C}_{\mathrm{e}} / \mathrm{C}_{0}(\%)$ as a function of throughput volume $(\mathrm{L})$ was used to represent the breakthrough curve in column systems. Result shows that the flow rate of $5 \mathrm{~mL} / \mathrm{min}$ was favorable to achieve higher removal rates with the percentage of cadmium was $57 \%$. At breakthrough time, the cadmium effluent concentration reached on $0.01 \mathrm{mg} / \mathrm{l}$ for both of flow rate.
\end{abstract}

Kata Kunci : Landfill leachate, packed bed column, adsorption, rice husk, cadmium.

\section{ABSTRAK}

Lindi yang dihasilkan dari TPA (Tempat Pembuangan Akhir) menimbulkan permasalahan lingkungan karena kandungan pencemarnya meliputi material organik, material anorganik, logam dan material beracun. Salah satu logam berat yang terdapat dalam lindi tersebut adalah kadmium. Penelitian ini bertujuan untuk mereduksi kadmium dalam lindi dengan menggunakan sekam padi yang diinstal dalam packed bed column. Lindi dipompakan dari tangki penampung lindi ke dalam packed bed column dan dialirkan dari atas ke bawah kolom secara gravitasi. Fokus pada penelitian ini adalah pengaruh laju alir influen terhadap kapasitas adsorpsi. Dimana lindi dialirkan dengan laju alir $5 \mathrm{~mL} /$ menit dan $10 \mathrm{~mL} /$ menit. Kurva breakthrough (titik jenuh) kolom dipresentasikan oleh hubungan antara rasio konsentrasi efluen-influen $C_{e} / C_{0}(\%)$ dan jumlah aliran lindi yang diolah dalam kolom. Hasil eksperimen menunjukkan bahwa persentase reduksi tertinggi dicapai pada laju alir $5 \mathrm{~mL} /$ menit yaitu $57 \%$. Waktu jenuh kedua laju alir (5 $\mathrm{mL} / \mathrm{menit}$ dan $10 \mathrm{~mL} /$ menit) tercapai saat konsentrasi efluen kadmium $0.01 \mathrm{mg} / \mathrm{L}$.

Keywords: Lindi TPA, packed bed column, adsorpsi, sekam padi, kadmium. 


\section{INTRODUCTION}

The utilization of landfill for final waste disposal tends to drive some hazard pollutants when landfill leachate is percolating into ground or entering into surface water. It can lead to serious environmental problems, since the leachate contains a large amount of organic matter (both biodegradable and non-biodegradable carbon), ammonia-nitrogen, heavy metals, chlorine organic and inorganic salts. Cadmium is often found in landfill leachate. It is derived from a variety of households and industries waste which some of them are from well-known toxic and carcinogenic agents. They have been recognized as dangerous pollutant contributing to the decrease of environmental quality.

Actually, by applying good controlled management, the amount and strength of leachate produced can be reduced, but still it cannot be vanished totally. Thus, combined treatment of physical, chemical, and biological have been usually used to improve the treatment efficiency of landfill leachates [8]. For some years, searching for effective and efficient technologies for treatment of landfill leachate has been intensified, mainly physic-chemical treatment. Physicochemical treatment has been found to be suitable not only for the removal of heavy metals from landfill leachate, but also for refining of biologically treated leachate. Before discharging, an additional effluent refining using physico-chemical treatments, such as chemical precipitation, activated carbon adsorption and ion exchange, can be carried out on-site.

Adsorption is one of common methods among physico-chemical treatments for heavy metal removal (Augustine et.al, 2007; Bhattacharya et.al, 2008; Bishnoi et.al, 2004; Feng et.al, 2004; Kiran et.al, 2006; Kumar and Bandyopadhyay, 2006; Mahvi, et.al, 2005; Mohan and Sreelakshmi, 2008; Sahu et.al, 2009; Sreejalekshmi et.al, 2009; Srivastava et.al, 2008; Teixeira and Zezzi 2004; Zulkali et.al, 2006). Today, several researchers perform byproduct from industrial, agricultural and biomass waste as adsorbent to remove heavy metals such as iron and cadmium as well as COD from either aqueous solution or real wastewater. Rice husk, for instance, a by-product of the rice milling industry, was selected as an adsorbent in several wastewater treatments by reason of its local availability, low production cost, insolubility in water, granular structure, high mechanical strength, and chemical stability (Sreejalekshmi et.al, 2009). Previous reports show that rice husk with or without chemical/ physical activation can lead to decrease in concentration of $\mathrm{Cr}$ (Bishnoi et.al, 2004), Cd (Kumar and Bandyopadhyay, 2006; Mahvi et.al, 2005; Mohan and Sreelakshmi, 2008; Srivastava et.al, 2008; Teixeira and Zezzi, 2004), Pb (Feng et.al, 2004; Mohan and Sreelakshmi, 2008), hydroquinone (Qi et.al, 2004), Cu (Mohan and Sreelakshmi, 2008), Zn (Mohan and Sreelakshmi, 2008), Mn (Mohan and Sreelakshmi, 2008), Hg (Zhou et.al, 2004 ), Fe (Daifullah et.al, 2004). ) and reactive dye (Ponnusami et.al, 2007). In this study reported here on the treatment of landfill leachate using rice husk packed bed column was investigated. The effects of varying flow rate as determinant factors influencing the adsorption process were studied.

\section{RESEARCH METHODOLOGY}

Raw rice husk was collected from local rice mill in Kuala Selangor, Malaysia. Adsorbent was prepared by firstly washing the collected rice husk for 2-4 times with tap water continued with distilled water to remove all dirt particles and impurities. Then, it was dried at $100^{\circ} \mathrm{C}$ in oven for 4 hours to get rid of moisture and impurities until the weight of rice husk become constant. Finally, it was ground with food processor with steel blades (National MK 110) and sieved to homogenous particle size lower than 600 $\mu \mathrm{m}$. Afterwards, the sieved rice husk was stored in air tight container at room temperature to be used.

Sample of leachate was obtained from Landfill of Core Competition Company, "Sungai Kembong", Semenyih, Kuala Selangor for several times sampling. The characteristic of fresh leachate sample was analyzed immediately as shown in Table 1. Preservation of leachate samples was performed by keeping it in refrigerator at $2^{\circ} \mathrm{C}$ temperature until used in packed bed column reactor. In this report, the analysis of 
parameter was focused on $\mathrm{pH}$, temperature, COD, iron and cadmium.

The value of $\mathrm{pH}$ was measured by Hanna pH meter while the temperature was checked by thermometer. COD was analyzed using closed reflux method and then measured by spectrophotometer. For iron and cadmium, sample of leachate was homogenized by shaking on plate stirred then filtered using Laboratory Scheleicher \& Schuell model filter paper from Germany with $0.45 \mu \mathrm{m}$ pore size and $47 \mathrm{~mm}$ diameter. Afterwards, the sample concentration was read by inductively couple plasma atomic electronic spectrophotometer (ICP-OES) (Perkin Elmer, Model: Optima 3000).

Table 1: Composition of Landfill Leachate in S. Kembong*

\begin{tabular}{lccc}
\hline \multicolumn{1}{c}{ Parameter } & Unit & \multicolumn{1}{c}{ Value } & Average \\
\hline $\mathrm{pH}$ & & $7.15-7.98$ & 7.74 \\
$\mathrm{COD}$ & $\mathrm{mg} / \mathrm{L}$ & $9000-15600$ & 11300 \\
Temperature & ${ }^{\circ} \mathrm{C}$ & $27-28$ & 27.6 \\
$\mathrm{Cd}$ & $\mathrm{mg} / \mathrm{L}$ & $0.228-105.73$ & 29.4 \\
$\mathrm{Fe}$ & $\mathrm{mg} / \mathrm{L}$ & $0.1925-14.428$ & 5.622 \\
\hline${ }^{*}$ random sampling obtained between May 2009 and August 2010
\end{tabular}

Packed bed column reactor is presented in Figure 1. The packed bed column was constructed of a vertical cylindrical Perspex column with a diameter of $5 \mathrm{~cm}$ and a depth of $50 \mathrm{~cm}$. The conical bottom has a divergence angel $15^{\circ}$ and a height of $5 \mathrm{~cm}$. Certain amount of rice husk was filled into column as a known bed height of column. It determined the dosage of rice husk. The packed rice husk was supported by two perforated polymer.

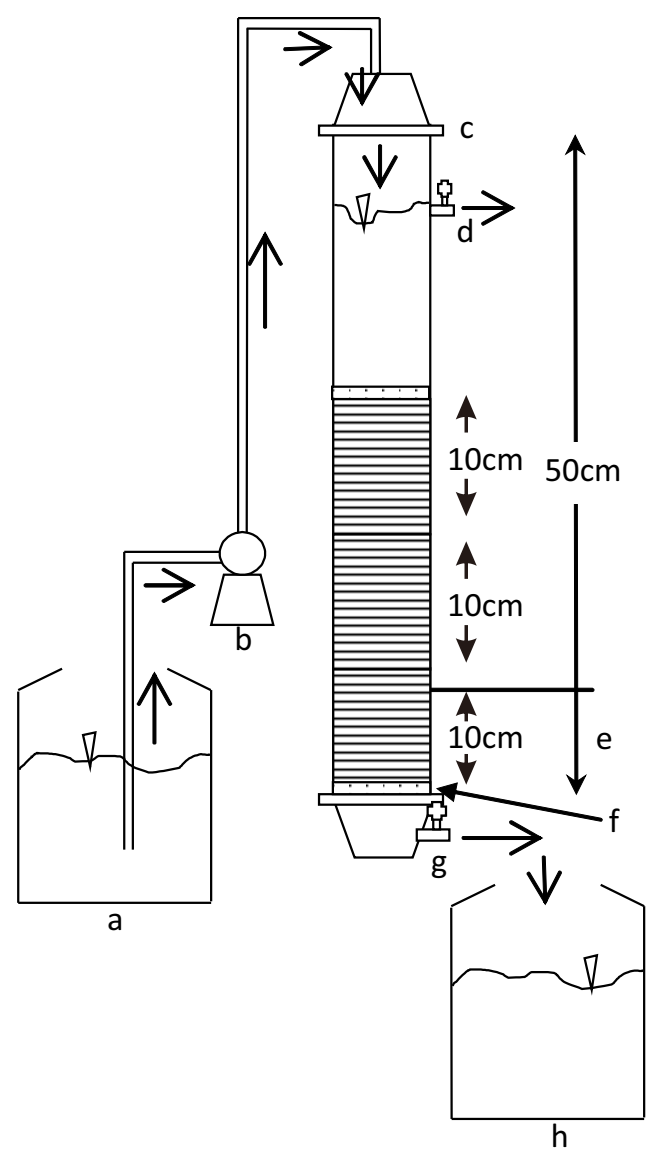

Legend
a. Influent wastewater tank
b. Influent feed pump
c. Perforated plate
d. Overflow valve
e. Adsorbent
f. Perforated polymer
g. Effluent wastewater valve
h. Effluent wastewater tank

Figure 1. Schematic diagram of experimental setup for column studies 
The perforated plastic plate was put on the top of the column to distribute landfill leachate onto the surface of adsorbent and to maintain a constant flow rate. It was also put on the bottom of column to prevent the adsorbent from leaching and clogging into the drainage area. Liquid influent was operated gravity down-flow by BT300-2J peristaltic pumps (Baoding Longer Precision Pump CO., Ltd). Reactor was also equipped with 1 overflow valve to avoid the over limit of sample in case the clogging and saturation occurs in reactor and 1 outlet valve to collect sample.

Some procedures was done to characterize the used rice husk. Composition of mineral and morphological features were identified by X-ray diffraction (XRD), a Siemens D-5000 system with $\mathrm{Cu}$ Ka radiation over $2 \theta$ from $5^{\circ}$ to $80^{\circ}$ at a rate of $0.05 \%$ second with range of wavelength $1.5406 \AA$ and a step time of 2 seconds. Morphological characteristics were examined by Scanning electron microscopy (SEM) (A Philip XL30 scanning electron microscope in secondary electron mode, equipped with energy dispersive X-ray, JEOL6335F-SEM, Japan). The presence of functional groups in adsorbent was identified by Fourier Transform Infrared spectrometer (Thermo nicolet, Model Magna 760). It was conducted at room temperature, using Pellet (pressed-disk) technique and chosen spectral range of 4000 to $400 \mathrm{~cm}^{-1}$. BET surface area, average pore diameter and total pore volume of the supports as well as the catalysts were determined by nitrogen adsorption-desorption isotherm at $77.35 \mathrm{~K}$ using the BET method in a Micromeritics Accusorb 2000 apparatus. Before measurement, each sample was degassed at $473 \mathrm{~K}$ for $4 \mathrm{~h}$.

Experiment was conducted in gravity down flow system. Landfill leachate was introduced into column packed with rice husk. Refilling of influent tank was done manually to be pumped into packed bed column by peristaltic pump. All the experiments were carried out at room temperature (range of $25^{\circ} \mathrm{C}-27^{\circ} \mathrm{C}$ ). The effluent samples were collected in regular time then filtered with membrane filter (Laboratory Scheleicher \& Schuell model filter paper from Germany with 0.45 and $\mu \mathrm{m}$ and $47 \mathrm{~mm}$ diameter) and stored in dark cool refrigerator for analysis of cadmium. The effect of liquid flow rate to adsorption capacity was studied by adjusting it to varying of flow rate in $5 \mathrm{~mL} / \mathrm{min}$ and 10 $\mathrm{mL} / \mathrm{min}$.

In the first 24 hours, samples were collected more often than in the following days to evaluate changes of cadmium concentration trend. Influent and effluent of cadmium concentrations were analyzed using ICP-OES. The effluent-influent concentration ratio $\mathrm{C}_{\mathrm{e}} / \mathrm{C}_{0}(\%)$ as a function of throughput volume (L) was used to represent the breakthrough curve in column systems. The volumetric throughput to reach breakthrough and shape of the breakthrough curve are essential in determining the operation and the dynamic response of an adsorption column as well as evaluating the adsorption capacity of the column.

The terms of breakthrough was defined as a curve ilustrating adsorbed metal concentration which was calculated from the result of differences value between the influent concentration of column. In other words, it is normalized as the ratio of effluent metal concentration to inlet metal concentration $\left(\mathrm{C}_{\mathrm{e}} / \mathrm{C}_{\mathrm{o}}\right)$ and computed as a function of time or volume of effluent for a given bed depth. Effluent volume $\left(\mathrm{V}_{\mathrm{e}}\right)$ can be calculated from Eq. (1):

$$
V e=Q t_{t o t}
$$

Here $t_{\text {tot }}$ and $Q$ are the total flow time (min) and volumetric flow rate $(\mathrm{mL} / \mathrm{min})$, respectively. The area under the breakthrough curve (A) obtained by integrating the adsorbed concentration (Cad; $\mathrm{mg} / \mathrm{L}$ ) versus $t$ (min) plot can be used to find the total adsorbed metal quantity (maximum column capacity). Total adsorbed metal quantity $\left(\mathrm{q}_{\mathrm{tot}} ; \mathrm{mg}\right)$ in the column for a given feed concentration and flow rate $(Q)$ is calculated from Eq. (2):

$$
Q_{\text {tot }}=\frac{Q A}{1000}=\frac{Q}{1000} \int_{t o}^{t 8} C_{a d} d t \quad \text { Eq. (2) }
$$

Total amount of metal ion sent to column $\left(m_{\text {tot }}\right)$ is calculated from Eq. (3):

$$
M_{\text {tot }}=\frac{C_{o} Q t_{\text {tot }}}{1000}
$$


Total removal is calculated from Eq. (4):

$$
\text { Total Removal (\%) }=\frac{Q_{\text {tot }}}{M_{\text {tot }}} * 100 \quad \text { Eq. (4) }
$$

Equilibrium metal uptake $\left(\mathrm{q}_{\mathrm{eq}}\right)$ in the column (or maximum capacity of the column) in the column is defined by Eq. (5) as the total amount of metal adsorbed $\left(\mathrm{q}_{\mathrm{tot}}\right)$ per gram of adsorbent $(\mathrm{m})$ at the end of total flow time (Gulensoy, 1984):

$$
\mathrm{q}_{\mathrm{eq}}=\frac{\mathrm{q}_{\mathrm{tot}}}{\mathrm{m}}
$$

\section{RESULTS AND DISCUSSIONS Characterization of rice husk}

General physical characteristics of rice husk are revealed in Table 2. The value of $\mathrm{pH}$ was neutral (6.670) and bulk density was $0.477 \mathrm{~kg} / \mathrm{m}^{3}$. Cadmium was better reduced in $\mathrm{pH}$ lower than 10 (acid to neutral). The value of micropoer area and total volume pore of rice husk was high enough to have high dispersive force acting on adsorbate molecule to provide space for storing more adsorbate molecules of cadmium. It illustrates that rice husk could adsorb cadmium from liquid well (Duong, 1998).

The rice husk contains high silica noted by by a diffuse maxima at $\mathrm{X}$-ray diffraction graph appearance which is approximately at $2 \theta=15^{\circ}$ and $2 \theta=23^{\circ}$. Silica existing in rice husk have significant function to keep adsorption process run well as reported by Lin and Chang, 2000 and Mohan and Sreelakshmi, 2008.

Table 2: Physical characteristics of rice husk

\begin{tabular}{lcc}
\hline \multicolumn{1}{c}{ Parameter } & Unit & Rice husk \\
\hline Bulk density & $\mathrm{kg} / \mathrm{m}^{3}$ & 0.447 \\
Particle size & $\mu \mathrm{m}$ & $\leq 600$ \\
moisture content & $\%$ & 8.955 \\
BET surface area & $\mathrm{m}^{2} / \mathrm{g}$ & 4.093 \\
Langmuir surface area & $\mathrm{m}^{2} / \mathrm{g}$ & 139 \\
Micropore area & $\mathrm{m}^{2} / \mathrm{g}$ & 2.175 \\
Average pore diameter & $\mu \mathrm{m}$ & 71.8 \\
Total pore volume & $\mathrm{cm}^{3} / \mathrm{g}$ & 0.007 \\
Micropore volume & $\mathrm{cm}^{3} / \mathrm{g}$ & 0.001 \\
Average $\mathrm{pH}$ & - & 6.67 \\
\hline
\end{tabular}

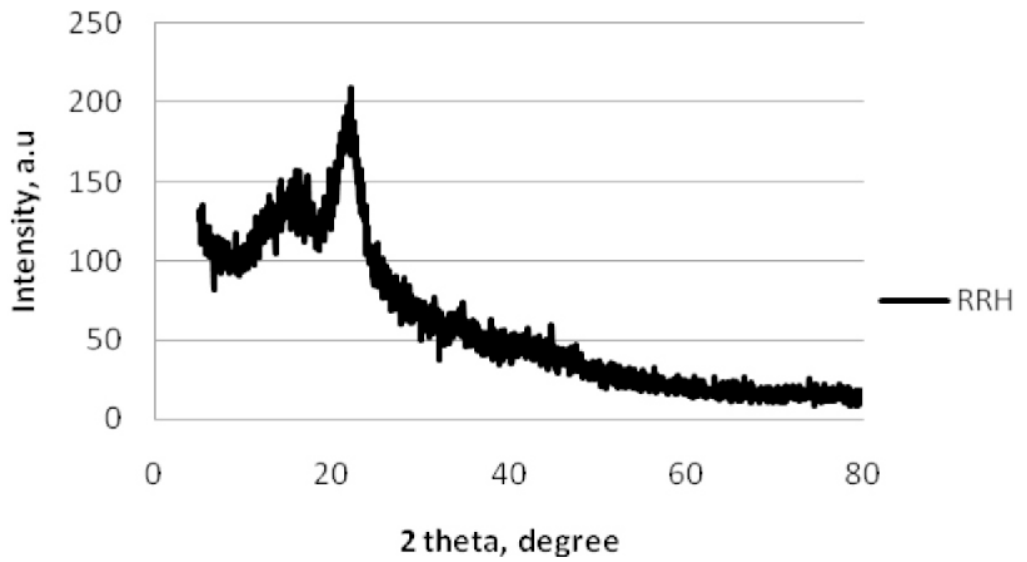

Fig.2. XRD - analysis for rice husk 


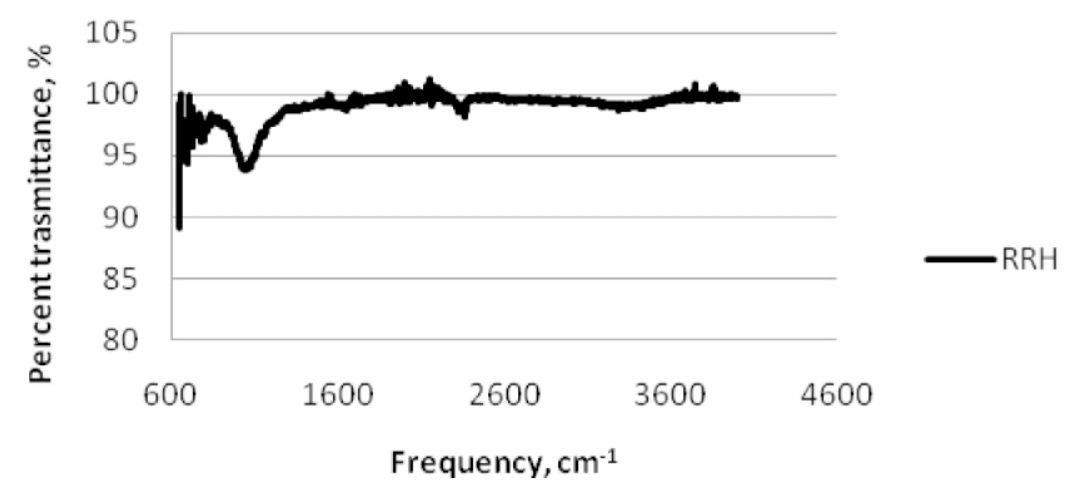

Fig.3. FTIR - analysis for virgin rice husk

According to the obtained results of FTIR, curve rice husk (Figure 3 ) shows identical trends. The peaks observed at about $651-740 \mathrm{~cm}^{-1}$ could be assigned to the phenyl groups $\mathrm{C}-\mathrm{H}$. The peak around $1630 \mathrm{~cm}^{-1}$ corresponds to $\mathrm{C}=\mathrm{O}$ stretch. The alkene was observed at the peaks of 1920 and $2030 \mathrm{~cm}^{-1}$. Other broad peaks between 3020 and $3290 \mathrm{~cm}^{-1}$ in rice husk were also observed that were attributed to $-\mathrm{OH}$ bond. The presence of $\mathrm{Si}-\mathrm{O}, \mathrm{Si}-\mathrm{H}, \mathrm{Si}-\mathrm{C},-\mathrm{CH}$ and $-\mathrm{OH}$ bond groups on the rice husk surface is responsible for adsorption (Srivastava et.al ,2008).

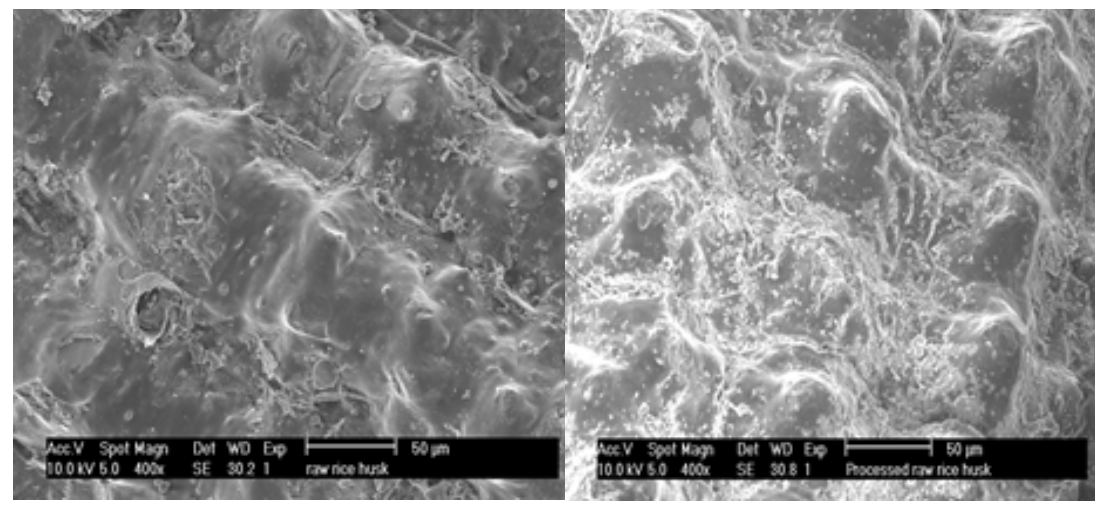

Fig. 4. RRH - SEM analysis of adsorbent (a) before and (b) after adsorption process.

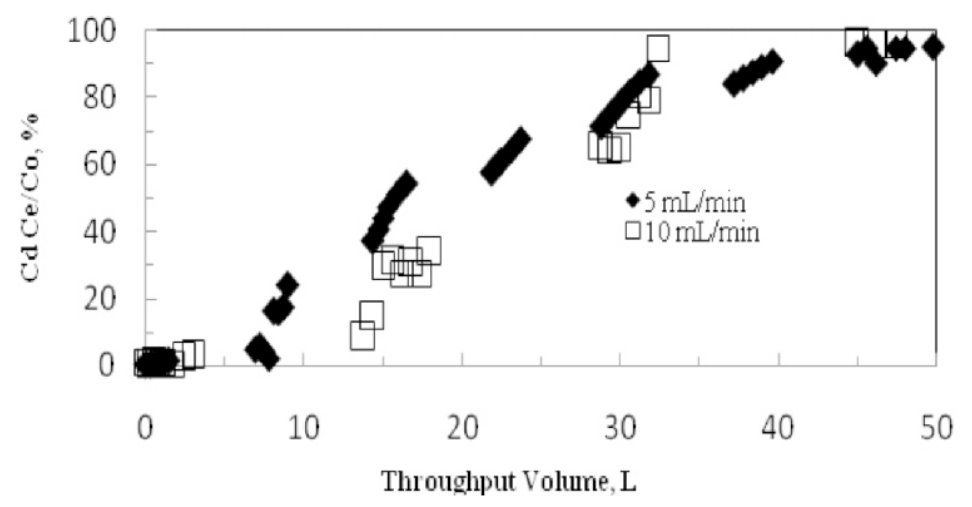

Fig.5. The experimental breakthrough curves for adsorption of cadmium from landfill leachate onto rice husk packed bed column at as a function of throughput volume in different flow rate. 
Table 4: The total adsorbed quantity $\left(\mathrm{q}_{\mathrm{tot}}\right)$, equilibrium uptake $\left(\mathrm{q}_{\mathrm{eq}}\right)$, total amount of metal ion through column $\left(\mathrm{M}_{\mathrm{tot}}\right)$ and total removal percentage for iron and cadmium adsorption from landfill leachate at RRH packed bed column

\begin{tabular}{cccccccc}
\hline $\begin{array}{c}\mathrm{Q} \\
(\mathrm{mL} / \mathrm{min})\end{array}$ & $\begin{array}{c}\mathrm{t}_{\text {tot }} \\
(\mathrm{min})\end{array}$ & $\begin{array}{c}\text { Co } \\
(\mathrm{mg} / \mathrm{L})\end{array}$ & $\mathrm{sOl}$ & $\begin{array}{c}\mathrm{q}_{\text {total }} \\
(\mathrm{mg})\end{array}$ & $\begin{array}{c}\mathrm{q}_{\mathrm{eq}} \\
(\mathrm{mg} / \mathrm{g})\end{array}$ & $\begin{array}{c}\mathrm{m}_{\text {tot }} \\
(\mathrm{mg})\end{array}$ & $\begin{array}{c}\text { Removal } \\
(\%)\end{array}$ \\
\hline 5 & 7560 & 0.8 & 4300.7 & 172.5 & 0.08 & 303.2 & 57 \\
10 & 5760 & 1.6 & 3001.4 & 47.3 & 0.21 & 907.8 & 52 \\
\hline
\end{tabular}

\section{Packed bed column study}

Figure 5 illustrates cadmium breakthrough curves in different flow rate, respectively. It indicates cadmium removal reached on $0.01 \mathrm{mg} / \mathrm{L}$ at flow rate $5 \mathrm{~mL} / \mathrm{min}$. This concentration of cadmium was higher than that of flow rate $10 \mathrm{~mL} / \mathrm{min}$. The raw landfill leachate was composed of cadmium concentrations of 0.802 and $1.576 \mathrm{mg} / \mathrm{L}$. Heavy metal removal efficiencies of columns as shown in Table 4 were computed based on cadmium concentrations entering the column. The results show the flow rate effected on concentration reduction. Higher reduction was achieved on lower flow rate $(5$ $\mathrm{mg} / \mathrm{L})$. Using equation 4 , the respective calculated cadmium removal efficiency obtaining were about $57 \%$ and $52 \%$.

Besides, the higher flow rate also increases medium exhaustion. The column within flow rate of $10 \mathrm{~mL} / \mathrm{min}$, for cadmium was exhausted or saturated (Ce/Co $>95 \%$ ) after $32.4 \mathrm{~L}$ throughput volume, earlier than those of column in flow rate of $5 \mathrm{~mL} / \mathrm{min}$. The clogging of column was detected in column system using flow rate of $10 \mathrm{~mL} / \mathrm{min}$ after $58.8 \mathrm{~L}$ throughput volume pumped through the column or after three days of column operation. For flow rate of $5 \mathrm{~mL} / \mathrm{min}$, the clogging was not still reached after six days operation of column. Li, (2008) also reported that the clogging in his column operation reaching after 7 days operation with low flow rate. The existence of biofilm which illustrate biological activity arround adsorbent surface in column assumed did not impact on adsorption capacity (Li, 2008).

\section{Acknowledgement}

The authors express their gratitude to UPGP financial support, and Mrs. Kalaiselvi for her helpful laboratory guidance during this study.

\section{REFERENCES}

Augustine, A.A., Orike, B.D., and Edidiong, A.D. 2007. Adsorption kinetics and modeling of $\mathrm{cu}(\mathrm{II})$ ion sorption from aqueous solution by mercaptoacetic acid modified cassava (Manihot Sculenta Cranz). Wastes, EJEAFChe $6(4), 2221-2234$.

Bhattacharya, A.K., Naiya, T.K., Mandal, S.N., and Das, S.K. 2008. Adsorption, kinetics and equilibrium studies on removal of $\mathrm{Cr}(\mathrm{VI})$ from aqueous solutions using different low-cost adsorbents. Chem. Eng. J. 137, 529-541.

Bishnoi, N. R., Bajaj, M., Sharma, N., \& Gupta, S. 2004. Adsorption of $\mathrm{Cr}(\mathrm{VI})$ on activated rice husk carbon and activated alumina. Bioresource Technology, 91(3), 305-307.

Daifullah, A. A. M., Awwad, N. S., \& El-Reefy, S. A. 2004. Purification of wet phosphoric acid from ferric ions using modified rice husk. Chemical Engineering and Processing, 43, 193201.

Duong, D. 1998. Adsorption analysis: equilibria and kinetics. London: Imperial College Press.

Feng, Q., Lin, Q., Gong, F., Shuici, S., \& Shoya, M. 2004. Adsorption of lead and mercury by rice husk ash. Journal of Colloid and Interface Science, 278, 1-8. 
Kargı, F., \& Pamukoglu, M. Y. 2004. Adsorbent supplemented biological treatment of pre-treated landfill leachate by fed-batch operation. Bioresource Technology 94, 285-291.

Kiran, B., Kaushik, A., and Kaushik, C.P. 2006. Response surface methodological approach for optimizing removal of $\mathrm{Cr}(\mathrm{VI})$ from aqueous solution using immobilized cyanobacterium. Chem. Eng. J. 126, 147-153.

Kumar, U and Bandyopadhyay, M. 2006. Fixed bed column study for Cd (II) removal from wastewater using treated rice husk. J. Haz. Waste Mat. B129, 253-259.

Li, C. 2008. Aqueous solutions and synthetic landfill leachate using low-cost natural adsorbents. Thesis of Master of Science (Engineering). Canada: Queen's University Kingston.

Lin, S.H and Chang, C.C. 2000. Treatment of landfill leachate by combined electrofenton oxidation and sequencing batch reactor method. J. Water Res. 34 4243-4249.

Mahvi, A.H., Alavi, N., and Maleki, A. 2005. Application of rice husk and its ash in Cadmium removal from aqueous solution. Pak. J. Bio. Sci. 8 (5), 721-725.

Ministry of Natural Resources and Environment. 1974. Akta kualiti alam sekitar (Environmental Quality Act). Kualu Lumpur, Malaysia.

Mohan, S and Sreelakshmi, G. 2008. Fixed bed column study for heavy metals removal using Phosphate treated rice husk. J. Haz. Waste Mat. 153, 75-82.

Ponnusami, V., Krithika, V., Madhuram, R., \& Srivastava, S. N. 2007. Biosorption of reactive dye using acidtreated rice husk: Factorial design analysis. Journal Hazardous Materials, 142, 397-403.
Qi, J., Li, Z., Guo Y and Xu, H. (2004). Adsorption of Phenolic compounds on micro and mesoporous rice huskbased active carbons. Mat. Che. Phys. J. 87, 96-101.

Robinson, A.H. (2004). Landfill leachate treatment: An article based on a paper with the same title, which was presented at the 5th international Conference on Membrane Bioreactors (MBR5); 9 pp.

Sahu, J.N., Agarwal, S., Meikap, B.C., Biswas, M.N. 2009. Performance of a modified multi stage bubble column reactor for lead (II) and biological oxygen demand removal from wastewater using activated rice husk. Haz. Waste Mat.161, 317-324.

Sreejalekshmi, G., Krishnan, K.A., and Anirudhan, T.S. (2009). Adsorption of $\mathrm{Pb}(\mathrm{II})$ and $\mathrm{Pb}(\mathrm{II})$-citric acid on sawdust activated carbon: Kinetic and equilibrium isotherm studies. J. Haz. Mat. 161, 1506-1513.

Srivastava, V. C., Mall, I. D., \& Mishra, I. M. 2008. Optimization of parameters for adsorption of metal ions onto rice husk ash using Taguchi's experimental design methodology. Chemical Engineering Journal 140, 136-144.

Teixeira Tarlye, C. R., \& Zezzi Arruda, M. A. 2004. Biosorption of heavy metals using rice milling by products. Characterization and application for removal of metals from aqueous effluents. Chemosphere, 54, 987 - 995.

Tinamaz, E., and Ongen, A. 2006. Risks posed by unsanitary landfill leachate to groundwater quality. In: Tellam, J.H. et al. (Eds.), Nato Science Series Vol. 74: Urban Groundwater Management and Sustainability. Netherland: Springer Publisher (pp. 259-268). 
Zhou, D., Zhang, L., Zhou, J., \& Guo, S. 2004. Development of a fixed-bed column with cellulose/chitin beads to remove heavy-metal ions. Journal of Applied Polymer Science, 94, 684 691.
Zulkali, M. M. D., Ahmad, A. L., \& Norulakmal, N. H. 2006. Oryza sativa L. husk as heavy metal adsorbent: Optimization with lead as model solution. Bioresource Technology 97, 21-25. 